\title{
Dental Retraction
}

National Cancer Institute

\section{Source}

National Cancer Institute. Dental Retraction. NCI Thesaurus. Code C82126.

A posterior movement of teeth. 